\title{
Örgütsel Adaletin Bağlamsal Performans Üzerine Etkisinde Etik Liderliğin Aracı Rolï ${ }^{1}$
}

\author{
Tuba BÜYÜKBESSE \\ Prof. Dr., Hasan Kalyoncu Üniversitesi, \\ İktisadi, İdari ve Sosyal Bilimler Fakültesi, İşletme Bölümü \\ tuba.buyukbese@hku.edu.tr \\ Orcid ID: https://orcid.org/0000-0003-4174-9870

\section{Hasan GÜNDOĞDU} \\ Doktora Öğrencisi, Hasan Kalyoncu Üniversitesi, \\ Sosyal Bilimler Enstitüsü, İşletme Ana Bilim Dalı \\ hasangundogdu.hgab@gmail.com \\ Orcid ID: https://orcid.org/0000-0003-0812-1790
}

\begin{abstract}
Öz
$\mathrm{Bu}$ araştırmanın amacı örgütsel adaletin bağlamsal performans üzerindeki etkisini incelemek ve bu süreçte etik liderliğin aracılık rolünü ortaya koymaktır. Bu amaçla özel güvenlik alanında faaliyet gösteren 700 çalışanı olan bir firmadan kolayda örnekleme yöntemi ile 320 adet anket toplanmıştır. Elde edilen veriler Spss ve Amos programları kullanılarak araştırma değişkenlerine ilişkin geçerlilik ve güvenilirlik analizleri yapılmıştır. Ardından regresyon analizi ile araştırma hipotezleri test edilmiştir. Araştırmanın sonucunda, örgütsel adaletin bağlamsal performansa etkisinde etik liderliğin tam aracı rolü olduğu tespit edilmiştir.
\end{abstract}

Anahtar Kelimeler: Örgütsel Adalet, Bağlamsal Performans, Etik Liderlik.

\footnotetext{
${ }^{1}$ Makale Geliş/Kabul Tarihi: 04.05.2021 / 11.08.2021

Künye Bilgisi: Büyükbeşe, T. ve Gündoğdu, H. (2021). Örgütsel adaletin bağlamsal performans üzerine etkisinde etik liderliğin aracı rolü. Kahramanmaraş Sütçü Imam Üniversitesi Sosyal Bilimler Dergisi, 18(2), 1080-1101. DOI: 10.33437/ksusbd.932711
} 
T.Büyükbese-H.Gündoğdu Örgütsel Adaletin Bağlamsal Performans...

\title{
The Mediating Role of Ethical Leadership in the Effect of Organizational Justice on Contextual Performance
}

\begin{abstract}
The purpose of this research is to examine the effect of organizational justice on contextual performance and to reveal the mediating role of ethical leadership in this process. For this purpose, 320 questionnaires were collected by convenience sampling method from a firm with 700 employees operating in the field of private security. The validity and reliability analyzes of the research variables were made by using SPSS and AMOS programs in the study. Then, the research hypotheses were tested with regression analysis. As a result of the research, it was determined that ethical leadership has a full mediator role in the effect of organizational justice on contextual performance.
\end{abstract}

Keywords: Organizational Justice, Contextual Performance, Ethical Leadership.

\section{GİRIŞ}

Örgütlerde adalet ve adalet algılarının örgütsel çalışmalarda zengin bir araştırma alanı olduğu son otuz yılın araştırmaları ile kanıtlanmıştır. Birçok araştırma, adaletin örgütsel ve davranışsal sonuçlar ile önemli bir ilişkisi olduğunu göstermiştir (Devonish ve Greenidge, 2010: 75). Örgüt içerisindeki kazanımların nasıl belirlendiği, nasıl dağıtıldığı ve dağıtılmasında adaletli olunup olunmadığı gibi konular örgütsel adalet algısında önemli rol oynar. Örgüt içerisindeki birçok örgütsel davranışın çıktı değişkenlerinin örgütsel adalet ile açılanabilir olduğu değerlendirilmektedir (Büyükyılmaz ve Ay, 2017: 212). Örgütsel adalet görüşü, çalışanların kurumlarda ödül gibi kaynakların tahsisi, prosedürleri ve süreçlerin adaletine ilişkin algılarını araştırmak olarak kabul edilir. $\mathrm{Bu}$ algılar, organizasyonlardaki performans gibi çeşitli çalışan sonuçları üzerinde önemli etkiye sahiptir (Tufail, Mahesar ve Pahtan, 2017: 270). Teori ve araştırma, görev ve bağlamsal performans arasında ayrım yapmıştır (ör. Borman ve Motowidlo, 1993; Campbell, 1990; Coleman ve Borman, 2000; Motowidlo ve Van Scotter, 1994). Görev performans1, bir işin asli görevlerini temsil eder ve bir işi diğerinden ayıran görevlerdir. Bağlamsal performans ise herhangi bir iş için resmi olarak gerekli olmayan isteğe bağlı davranışlardır. Ancak bağlamsal performans tüm işlerin sosyal bağlamını oluşturur (Jawahar ve Carr, 2006: 331). Çalışanların algıladıkları örgütsel adalet ve liderlerin sergiledikleri etik davranış örgütlerin başarısında önemli bir yer tutmaktadır (İnak, Özkoç ve Kırıcı, 2018: 288). Etik liderler, dürüstlük, adalet ve güvenilirlik gibi etik ilkelerle tutarlı 
özellikler sergilerler. Bu liderler adil ve dengeli kararlar alırlar ve bu kararların etik sonuçları açısından uygunluğunu aktif olarak değerlendirirler. Etikle ilgili iletişim kurmak ve çalışanları etik uygunluk temelinde ödüllendirmek gibi ahlaki yönetim davranışlarını sergileyerek, performansın artmasını sağlarlar (Piccolo vd., 2010: 261).

Örgüt çalışanlarının örgüte karşı tutumları üzerinde önemli etkilere sahip olan örgütsel adaletin çalışanların bağlamsal performansı üzerine etkisinde etik liderliğin aracı rolünü tespit edebilmek amacıyla gerçekleştirilen bu çalışmada, öncelikle örgütsel adalet, bağlamsal performans ve etik liderlik kavramları ele alınmıştır. Daha sonra örgütsel adalet algısı ile bağlamsal performans, örgütsel adalet ile etik liderlik algısı ve etik liderlik algısı ile bağlamsal performans arasındaki ilişkiye değinilmiş ve buna ilişkin olarak özel güvenlik firması çalışanlarına yönelik gerçekleştirilen alan araştırmasına ve sonuçlarına yer verilmiştir.

\section{KAVRAMSAL ÇERÇEVE}

\section{Etik Liderlik}

Liderlik, dönüşümsel etkisinden dolayı aynı hedefleri olan lider ve astları arasında ahlaki bir bağlllık geliştirir (Aronson, 2001: 247). Etik liderler dürüst güvenilir, ahlaki ve ilkeli karar vericiler olarak değerlendirilir. Çalışanlar, kendilerinin çıkarlarını koruyan ve kendilerine iyi şekilde davranan ve kendilerini önemseyen bir lidere sahip olduklarında liderlerinin kendilerine bağlı olduğu çıkarımında bulunurlar. Bunun sonucunda yüksek sadakat, duygusal bağ ve karşıllklı destek oluşur. Etik ilişkiler sosyal değişim ve karşıllklılık normları üzerine inşa edildiğinden etik liderler bunu oldukça önemsemektedirler. Etik liderler astlarının faydaları, etik davranışları, uygunsuz davranışlarının maliyeti ve sonrasında astlarını sorumlu tutmak için dengeli ceza kullanımı gibi konularla ilgili bilgi verir. Etik liderler astlarının fikirlerini otosansür olmaksızın talep eder, onlarla güvene dayalı ilişkiler kurarlar (Walumbwa vd, 2011: 205-206). Etik liderlik, bir örgütteki üyelerin arasındaki uygun davranışlara katkı sağlayan çalışanların davranışları ve insanlar arasındaki iletişimde karar verme sürecinde karşıllklı iletişimi benimseyen liderlik biçimidir (Akdoğan ve Demirtaş 2014: 109) Liderin etik anlayışı iş üzerinde önemli derecede etkilidir. Aynı zamanda söz konusu bu durum beraber çalıştığı alt çalışanlarının üzerinde etkisinin olduğunu da göstermektedir (Tuna, Bircan ve Yeşiltaş, 2012: 144). Brown, Trevino ve Harrison (2005) dürüstlük, etik standartlar ve çalışanlara adil muamele kombinasyonunun, etik liderliğin temel taşları olduğunu belirtmiştir. Trevino ve Brown (2004), gerçek anlamıyla etik liderliğin, etik davranışı uygulayarak, yöneterek ve herkesi bundan sorumlu tutarak etik davranışı desteklediğini öne sürmüştür. İş hayatında liderler kendi davranışlarıyla ve 


\section{T.Büyükbese-H.Gündoğdu Örgütsel Adaletin Bağlamsal Performans...}

davranış özellikleriyle çalışanlarına örnek teşkil eder. Etik liderlikte "karakter" hayati bir önem taşırken doğruluk ise esas ilkedir. Etik liderliğin temelinde diğerlerinin haklarını önemseme ve saygı duyma vardır (Uğurlu, Sincar ve Çınar, 2013: 268).

\section{Bağlamsal Performans}

İşletmelerin, başarılı olması ve sürekliliğini sağlayabilmesi yüksek performans göstermeleri ile mümkündür. Başka bir deyiş ile örgütlerin sürekliliği örgüt üyelerinin verimli ve etkili bir şekilde çalışmaları ile sağlanabilir (Yıldız ve Çakı 2018:72). Kişisel benliklerini iş rollerine yatıran çalışanların bu role daha geniş bir anlayış ile sahip olduklarını ve genel olarak bir organizasyonun içinde yer alan insanların organizasyondaki işlerine ait resmi sınırlarının dışına çıkmaları büyük bir olasıdır (Christian, Garza ve Slughter, 2011:101). Bu nedenle iş performansı görev ve bağlamsal performans olmak üzere iki boyutta incelenmektedir (Aslan ve Yıldırım, 2016:105). Görev performansı her işin kendisine özgü, yapılabilmesi için asıl olan, olmazsa olmaz sorumlulukları ifade etmektedir. Bağlamsal performans ise, görev performansına katkı sağlayan psikolojik ve sosyal bağlamın devam etmesi ve çoğalmasına etki eden tutumlardır (Polatc1, 2014: 116). Bağlamsal performans iş arkadaşları amirler ve müşteriler ile ilişkilerin yanı sıra öz disiplin ve kararlılık davranışları ile ilişkilidir (VonScotter, Motowidlo ve Cross, 2000: 527). Örgüt içindeki diğer iş arkadaşlarına yardım etme, iş arkadaşlarıyla iş birliği yapabilme, işleri için gereğinden daha fazla fedakarlıkta bulunma, örgütsel kurallara ve normlara uyum sağlama, örgütün örgütsel hedeflere ulaşılmasına katkı sağlama gibi davranışlar bağlamsal performansa örnek olarak sayılabilir (Öcel, 2013: 38). Örgütsel başarı için gerekli unsurların içinde yer alan bağlamsal performans, örgütsel verimliliğin sağlanması için de önem arz etmektedir. Ayrıca kurumsal performansın artırılmasında başrol etkiye sahip bir kavramdır. Çünkü bağlamsal performans kişiler arası pozitif yönlü davranışları destekleyerek, örgütsel işlemlerin yerine getirildiği sosyal motivasyon iklimini zenginleştirmektedir (Ünlü ve Yürür, 2011:186).

\section{Örgütsel Adalet}

Örgütsel adaletin temeli, Adams'ın “Adalet Teorisi”nden gelmektedir (Yeniçeri, Demirel ve Seçkin, 2009:84). Bu teori, çalışanların sahip olduğu iş çıktılarını algıladıkları iş girdileri ile karşılaştırdığını belirtmektedir. Çalışanların bu karşılaştırmada eşitsizlik algılaması durumunda yer aldığı örgütüyle, üstleriyle ve işleri ile ilgili tutumlar geliştirmektedir (Büyükyılmaz ve Ay, 2017:212). Örgütlerde adalet, örgütlerdeki çalışanların ödül ve cezalarının ne şekilde yönetildiği ve dağıtıldığı ile ilgili kurallar ve sosyal normlar şeklinde ifade edilmektedir. Söz konusu bu kural ve normlar ödül ve cezaların ne şekilde 
dağıtılacağını, bu dağıtım kararlarının alınma şeklini gösteren işlem ve kişiler arası uygulamalar ile ilgili kurallar ve normlar olarak tanımlanabilir (Baş ve Şentürk, 2011:33). Bir organizasyonda adalet, çalışanın tutumunu büyük ölçüde etkileyecektir, bu da organizasyonel performansa etki edecek ve işverenler ile çalışanları arasındaki çatışmayı azaltacaktır (Novitasar vd., 2020: 97). İşyerinde örgütsel adaletsizliğinin olması örgütsel ilişkileri bunun sonucunda örgütsel faaliyetleri ve nihayetinde örgütsel başarıyı olumsuz yönde etkileyecektir (Chegini, 2009: 173) Örgütsel adalet, adalet algısının işe yansıması başka bir deyişle iş yeri ile ilgili adalet algısıdır. Örgütsel adalet dağıtımsal, işlemsel ve etkileşimsel adaletolmak üzere üç bileşenden oluşmaktadır.

Dağıtımsal Adalet: Çalışanların kazanımlarının, adil bir şekilde dağıtılması konusunda algılarını tanımlamaktadır. Dağıtımsal adalet örgüt çalışanlarının kazanımlarının, gösterdikleri performans doğrultusunda doğru ve gerçekçi bir şekilde değerlendirilip değerlendirilmediği ile ilgili algılamaları olarak ifade edilebilir (Polat ve Celep, 2008: 309) Çalışanlar arasında iş ile ilgili kazanımlarının adaletli bir şekilde dağıtılıp dağıtılmaması, çalışanların işe olan katkısını etkilemektedir (Nasurdin ve Khuan, 2011: 277).

İşlemsel Adalet: Dağıtımsal adalet çalışanların kendileri ile ilgili kararların adil olup olmaması ile ilgilenirken, İşlemsel adalet ise kişilerin karar sürecine dahil olmaları ve karar sürecindeki objektiflikle ilgili algılarıly ilgilenmektedir (Yeniçeri, Demirel ve Seçkin, 2009:84). İşlemsel adalet, kazanım kararlarının alınmasında kullanılan yöntem ve süreçler ile ilgili adalet algısı şeklinde tanımlanmaktadır (Titrek, 2009:554). Çalışanlara, elde edecekleri kazanımlar ile ilgili süreçte söz hakkı verilmesi, sonuçlar ile ilgili hoşnutsuzluğu azaltır (Tokgöz, 201: 369).

Etkileşimsel Adalet: Etkileşimsel adalet kavramı, örgütlerin insani ve sosyal tarafını ele alır; yani karar organlarının veya ödülleri ve kaynakları yönlendirenlerin adaleti yaşayacak olanlara (çalışanlara) karşı davranış biçimlerini içermektedir. Yöneticilerin karar süreçlerinde kişilere ne ve nasıl ifade ettiği ile ilgilidir. Karar aşamasında kullanılan prosedürler ve uygulamaların karar organlarınca uygulanma biçimi ile ilgili olan etkileşime dayalı boyutu inceler (İşcan ve Sayın 2010: 197).

\section{ARAŞTIRMA MODELINININ VE HIPOTEZLERINN OLUŞTURULMASI}

\section{Örgütsel Adalet ve Bağlamsal Performans İlişkisi}

Örgüt çalışanlarının örgütsel adalet algıları, örgütsel başarıyı olumlu veya olumsuz yönde etkileyen bir unsurdur (Poyraz, Kara ve Çetin, 2009:73). Örgüt çalışanları çalıştıkları örgütte diğer çalışanlarla kendilerini mukayese ederler. Örgüt kuralların bütün çalışanlara eşit uygulanmasını, ücret, iş, izin, sosyal 


\section{T.Büyükbese-H.Gündoğdu Örgütsel Adaletin Bağlamsal Performans...}

imkanlar gibi konularda eşit davranılmasını isterler. Adalet algısının odağında çıktılar ve bu çıktıların mukayesesi değil aynı zamanda örgütteki mevcut kurallar ve bunların uygulanış şekli ve kişiler arası etkileşim de vardır (Özdevecioğlu, 2003:78). Örgütsel başarıda rol oynayan faktörlerin içinde bağlamsal performans önemli bir yere sahiptir. Bağlamsal performans örgütlerin verimli çalışma ortamını besler ve örgüt çalışanların motivasyonunu arttırır (Ünlü ve Yürür, 2011:186). Çalışanlara adil davranılan, örgütte tüm imkanların eşit dağıtıldığı düşünülen bir ortamda çalışanların psikolojik ve sosyal yönüyle ilintili bağlamsal performansın da yüksek olması beklenir.

Örgütsel adalet ve bağlamsal performans ilişkisi ile ilgili literatürde çeşitli sektörlerde yapılmış birçok çalışma yer almaktadır (Doğan, 2018; Turfail, Mahesar ve Pahtan, 2017; Elamin ve Alomaim 2011; Devonish ve Greenidge, 2010; Wang, vd. 2010; Nasurdin ve Khuan, 2007; Robinson, 2004). Örneğin Turfail, Mahesar ve Pahtan, (2017) çalışmalarında dağıtım adaleti ve prosedürel adalet ile bağlamsal performans arasındaki ilişkiye değinmiş ve araştırmanın sonucunda dağıtım adaleti ve prosedürel adaletinin bağlamsal performans üzerinde anlamlı ve pozitif bir etkiye sahip olduğu sonucunu elde etmiştir.

Literatür incelemesinden sonra hizmet sektöründe yer alan özel güvenlik çalışanlarının örgütsel adalet algıları ve bağlamsal performansları arasındaki ilişkiye yönelik aşağıdaki hipoteze yer verilmiştir.

H1: Örgütsel adaletin bağlamsal performans üzerinde pozitif yönde anlamlı etkisi vardır.

\section{Örgütsel Adalet ve Etik Liderlik İlişkisi}

Gündelik hayatta haklılık ve doğruluğun ifadesi olan adalet algısı bir davranış tutum ve hareketin adalete uygunluğunu ve bireylerin doğruluk ve dürüstlüğünü ifadesi için kullanılmaktadır. Örgütlerde ise örgüt liderlerinin çalışanlarına karşı adil olup olmamaları ile ilgili değerlendirilmektedir. Örgütsel adalet algısı, örgüt çalışanlarının üstlerin kendilerine karşı adil olup olmaması ile ilgili değerlendirmeleridir (Yeşiltaş, Çeken ve Sormaz, 2012 :21).

Etik değerler ve dürüstlük bir liderde bulunması gereken en önemli özelliklerdendir. Lider bu özellikleri bulundurmakla birlikte çevresine yansitmalıdır (Akdoğan ve Demirtaş, 2014:109). Örgütlerde liderler etik davranışlar sergiliyorsa çalışanların arasında adile ve ahlaki ilkeler çerçevesinde kararlar alır. Bunun sonucunda da etik liderlikle örgütsel adalet arasında anlamlı ilişki oluşur. Literatür incelendiğinde örgütsel adalet ile etik liderlik arasındaki ilişki bulunduğuna dair çeşitli çalışmalar bulunmuştur (Halbussi vd., 2019; İnak, Özkoç ve Kırıcı, 2018; Sonğur, Özer ve Şahin, 2017; Büyükyılmaz ve Ay, 2017, gibi) Bu sonuçlar altında hizmet sektöründe yer alan özel güvenlik çalışanlarının 
örgütsel adalet algıları ve etik liderlik algıları arasındaki ilişkiye yönelik aşağıdaki hipotez geliştirilmiştir.

H2: Örgütsel adaletin etik liderlik üzerinde pozitif yönde anlamlı etkisi vardır.

\section{Etik Liderlik ve Bağlamsal Performans İlişkisi}

Etik liderlik çalışanlar arası ve çalışanlar aracılığıyla, dürüst, adaletli ve güven veren bir yönetimin göstergesidir. Etik lider, karşılıklı iletişim aracılığıyla ahlaki olarak güçlü, pekiştirme ve karar vermeyi hedefler (Karadal ve Özsungur, 2017:665). Bağlamsal performans; örgüt çalışanlarının sorunlarıyla ilgilenmek, etik normların savunulması vb. konuları vurgulamaktadır (Ünlü ve Yürür, 2011:185). Literatür ele aldığında etik liderlik çalışmalarının liderin özellikleri ve takipçileri yönlendirmesi ile ilgili olduğu görülmektedir (Bıyık, Şimşek ve Erden, 2017:62). Etik liderlik ile bağlamsal performans arasındaki ilişki üzerine yapılan birçok çalışma bulunmaktadır (Yasan, Doğan ve Mengi 2019; Bıyık, Şimşek ve Erden, 2017, Tamer, 2017; Sabır, vd. 2012, vb.).

Literatür incelemesinden sonra hizmet sektöründe yer alan özel güvenlik çalışanlarının etik liderlik algıları ve bağlamsal performansları arasındaki ilişkiye yönelik aşağıdaki hipotezler oluşturulmuştur.

H3: Etik liderliğin bağlamsal performans üzerinde pozitif yönde anlamlı etkisi vardir.

H4: Örgütsel adaletin bağlamsal performans üzerindeki etkisinde etik liderliğin aracılık rolü bulunmaktadır.

\section{Araştırmanın Yöntemi}

$\mathrm{Bu}$ araştırmada, nicel araştırma yöntemi kullanılmıştır. Veriler hazırlanan anketler aracıllğı ile toplanmıştır. Verilerin analizinde Spss ve Amos programları kullanılarak öncelikle kullanılan ölçeklerin geçerlilik ve güvenilirlik analizi yapılmıştır. Daha sonra regresyon analizi ile araştırma hipotezleri test edilmiştir.

\section{Araştırmanın evreni ve örneklemi}

Araştırmanın evrenini özel güvenlik alanında faaliyet gösteren bir işletmede çalışan 700 kişi oluşturmaktadır. Kolayda örnekleme yöntemi seçilerek dağıtılan 500 anketten 320 anket yanttlanarak geri dönmüş ve değerlendirmeye tabi tutulmuştur. Uygulanan anketler için Hasan Kalyoncu Üniversitesi Sosyal ve Beşeri Bilimler Etik Kurulundan 28.12.2020 tarih ve E.2012280014 say1lı etik kurul izni alınmıştır. 


\section{T.Büyükbese-H.Gündoğdu Örgütsel Adaletin Bağlamsal Performans...}

\section{Araştırmanın ölçekleri}

\section{Örgütsel Adalet Ölçeği}

$\mathrm{Bu}$ araştırmada Colquitt (2001) tarafindan geliştirilen Dalgın (2015) çalışmasında kullandığı 13 maddeli ve 3 boyutlu Örgütsel Adalet Ölçeği, kullanılmıştır. Ölçek için yanıtlar, 5'li Likert ölçeği ş̧eklinde sağlanmıştır (1=Kesinlikle katılmıorum, 5=Kesinlikle katıllyorum). Dalgın, (2015) çalışmasında yaptığı analiz sonucunda ölçeği üç boyutlu ve Cronbach alfa değerini Dağıtımsal Adalet 0,943; İşlemsel Adalet 0,858; Etkileşimsel Adalet 0,879 olarak bulduğunu belirtmiştir.

$\mathrm{Bu}$ ölçek için yapılan açıklayıcı faktör analizi sonucunda ölçeğinin KaiserMeyer-Olkin Measure of Sampling Adequacy değeri 0,875 dir. Bartlett's Test of Sphericity testi istatiksel $(\mathrm{p}=000)$ anlamlı olarak tespit edilmiştir. Açıklanan toplam varyans oran 1 ise $\% 86,77$ 'dir. Oblimin döndürme sonrasında ölçeğin üç boyut olduğu tespit edilmiştir. Bu boyutlar işlemsel adalet, etkileşimsel adalet ve dağıtımsal adalet şeklinde adlandırılmıştır. Doğrulayıcı faktör analizi sonucundasağlanan uyum iyiliği değerleri şunlardır; [c2 $=159,050 ; \mathrm{DF}=61$; c2/Sd=2,60; AGFI=0,91; GFI=0,93; CFI=0,97; IFI=0,97; RMSEA=0,07; $\mathrm{NFI}=0.96 ; \mathrm{RMR}=0.04]$. DFA uyum iyiliği indeksi değerlerinin iyi uyum ve kabul edilebilir aralıkta olduğu gözlenmiştir. Cronbach alfa 0,894 olarak bulunmuştur. Yapılan analiz sonucunda model uyum indekslerini iyileştirmek amacıyla maddeler arasında modifikasyonlar yapılmış ve modifikasyon sonrası elde edilen bulgulara Şekil 1'de yer verilmiştir.

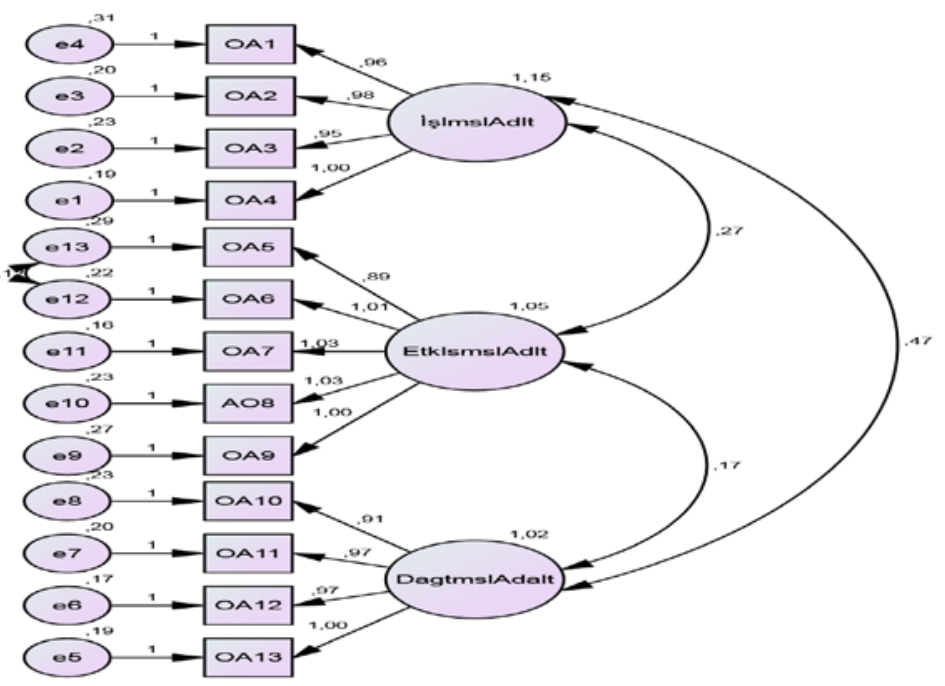

Şekil 1. Örgütsel Adalet Ölçeği DFA Diyagramı 


\section{Etik Liderlik Ölçeği}

Bu araştırmada Brown vd. (2005: 126) tarafından oluşturulan, Yılmaz (2018) çalışmasında kullanılan tek boyutlu 10 maddeli etik liderlik ölçeğinin, uygun olacağ1 düşünülmüştür. Ölçek için yanıtlar, 5'li Likert ölçeği şeklinde sağlanmıştır. Yılmaz, (2018) Çalışmasında yaptığı analiz sonucunda Ölçeği üç boyutlu ve Cronbach alfa değerini 0,949 olarak bulduğunu belirtmiştir.

Bu ölçek için yaptığımız açıklayıcı faktör analizi sonucunda ölçeğinin KaiserMeyer-Olkin Measure of Sampling Adequacy değeri 0,964dir. Bartlett's Test of Sphericity testi istatiksel $(\mathrm{p}=000)$ anlamlı olarak tespit edilmiştir. Açıklanan toplam varyans oranı ise \% 77,44'dür. Oblimin döndürme sonrasında ölçeğin tek boyut olduğu tespit edilmiştir. Doğrulayıcı faktör analizi sonucunda sağlanan uyum iyiliği değerleri şunlardır; [c2= 81,413; $\mathrm{DF}=32 ; \mathrm{c} 2 / \mathrm{Sd}=2,54 ; \mathrm{AGFI}=0,91$; GFI=0,95; CFI=0,98; IFI=0,98; RMSEA=0,07; NFI=0.97; RMR=0.02]. DFA uyum iyiliği indeksi değerlerinin iyi uyum ve kabul edilebilir aralıkta olduğu gözlenmiştir. Cronbach alfa 0,968 olarak bulunmuştur. Yapılan analiz sonucunda model uyum indekslerini iyileştirmek amaciyla maddeler arasında modifikasyonlar yapılmış ve modifikasyon sonrası elde edilen bulgulara Şekil 2'de yer verilmiştir.

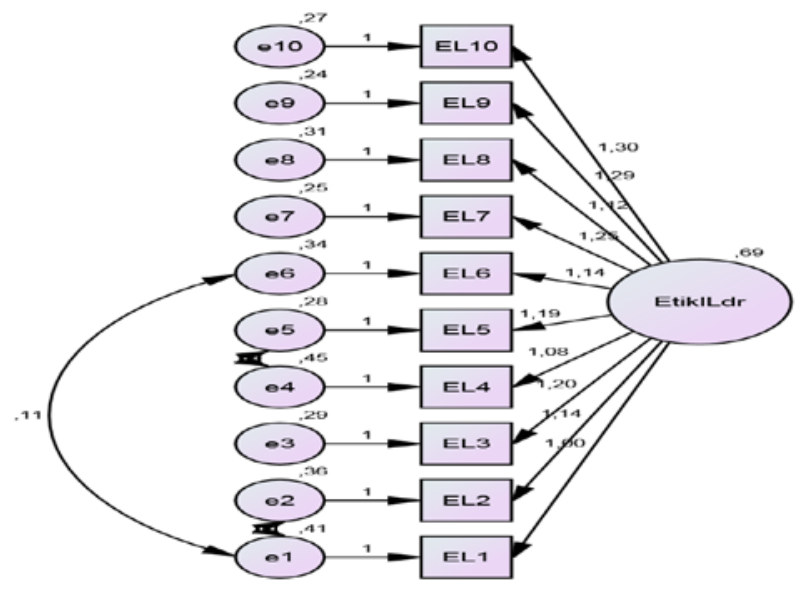

Şekil 2. Etik LiderlikÖlçeği DFA Diyagramı 


\section{T.Büyükbese-H.Gündoğdu Örgütsel Adaletin Bağlamsal Performans...}

\section{Bağlamsal Performans Ölçeği}

$\mathrm{Bu}$ ölçek için yapılan araştırmalar sonucu Jawahar ve Carr (2007) tarafindan bağlamsal performansı ölçmeye yönelik olarak hazırlanmış, Şahin (2018) çalışmasında kullanılan tek boyutlu 7 maddeli Bağlamsal Performans ölçeği, bu çalışma için de uygun olacağı düşünülmüştür. Ölçek için yanıtlar, 5'li Likert ölçeği şeklinde sağlanmıştır. Şahin(2018) çalışmasında yaptığı analiz sonucunda Ölçeği üç boyutlu ve Cronbach alfa değerini 0,907 olarak bulduğunu belirtmiştir.

$\mathrm{Bu}$ ölçek için yapılanaçıklayıcı faktör analizi sonucunda ölçeğinin KaiserMeyer-Olkin Measure of Sampling Adequacy değeri 0,882dir. Bartlett's Test of Sphericity testi istatiksel $(\mathrm{p}=000)$ anlamlı olarak tespit edilmiştir. Açıklanan toplam varyans oranı ise \% 60,21'dir. Oblimin döndürme sonrasında ölçeğin tek boyut olduğu tespit edilmiştir. Doğrulayıcı faktör analizi sonucunda sağlanan uyum iyiliği değerleri şunlardır; [c2=26,645; $\mathrm{DF}=12 ; \mathrm{c} 2 / \mathrm{Sd}=2,22$; $\mathrm{AGFI}=0,94$; GFI=0,97; CFI=0,98; IFI=0,98; RMSEA=0,06; NFI=0.97; RMR=0.04]. DFA uyum iyiliği indeksi değerlerinin iyi uyum ve kabul edilebilir aralıkta olduğu gözlenmiş̧tir. Cronbach alfa 0,887 olarak bulunmuştur. Yapılan analiz sonucunda model uyum indekslerini iyileştirmek amacıyla maddeler arasında modifikasyonlar yapılmış ve modifikasyon sonrası elde edilen bulgulara Şekil 3'de yer verilmiştir.

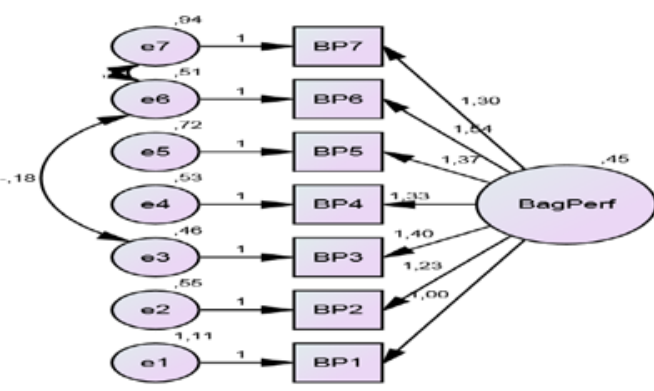

Şekil 3. Bağlamsal Performans Ölçeği DFA Diyagramı 
Tablo 1. Ölçek Faktör Analiz Sonuçları

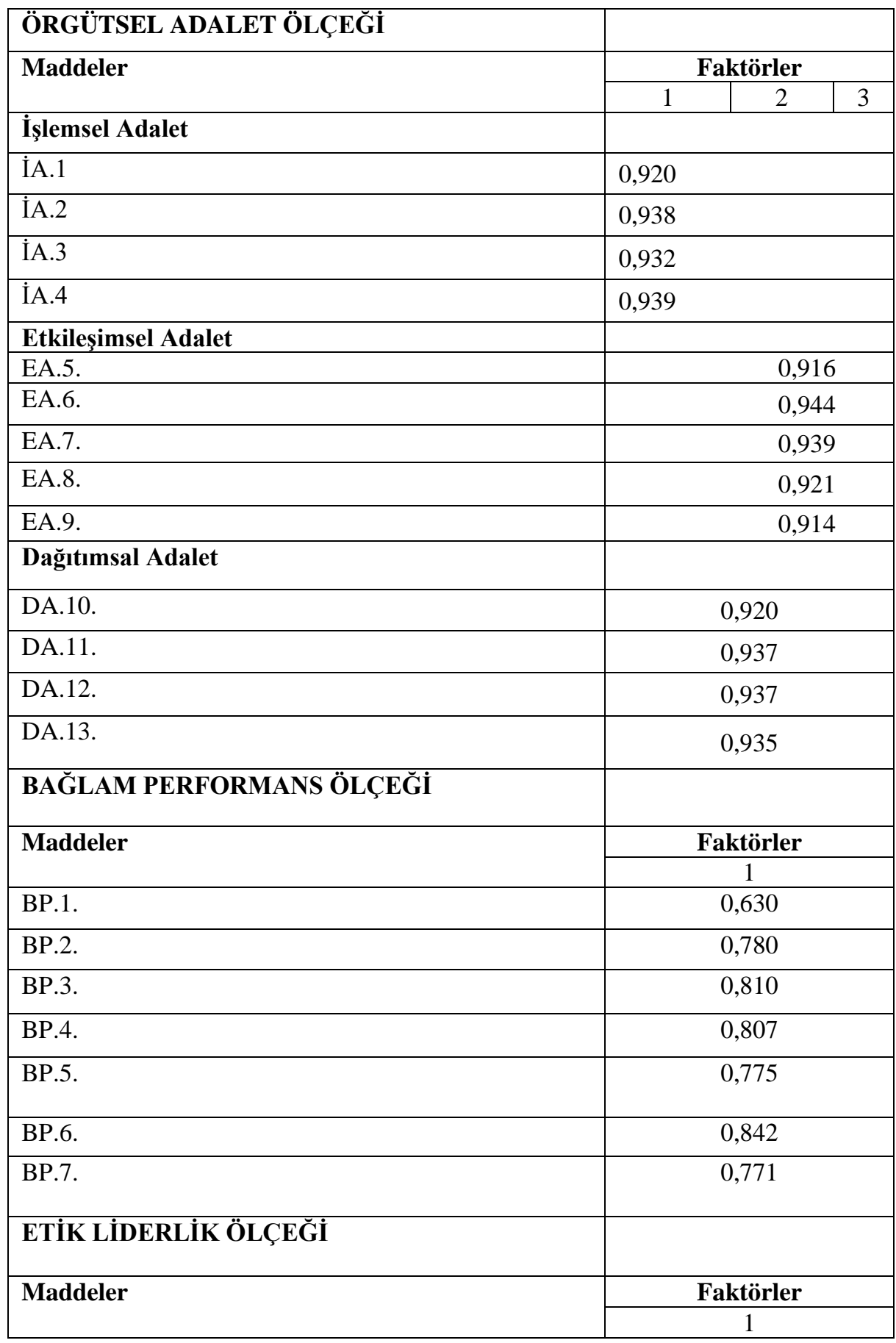


T.Büyükbese-H.Gündoğdu Örgütsel Adaletin Bağlamsal Performans...

\begin{tabular}{|l|c|}
\hline ET.1. & 0,836 \\
\hline ET.2. & 0,874 \\
\hline ET.3. & 0,890 \\
\hline ET.4. & 0,837 \\
\hline ET.5. & 0,900 \\
\hline ET.6. & 0,881 \\
\hline ET.7. & 0,903 \\
\hline ET.8. & 0,872 \\
\hline ET.9. & 0,906 \\
\hline ET.10. & 0,898 \\
\hline
\end{tabular}

\section{Bulgular}

Verilerin analizinde SPSS 21 programından yararlanılmıştır. Kullanılacak analiz yöntemlerinin belirlenmesinde ölçek verilerine normal dağılım testi uygulanmıştır. Verilerin Skewness (çarpıklık) ve Kurtosis (basıklık) değerlerinin normallik testi sonucunda $-1,5$ ile $+1,5$ arasında aldıkları değerlerle normal dağılım sağladıkları (Tabachnick ve Fidell, 2013) ve parametrik testler uygulanabileceği görülmüştür(Tablo 1).

Tablo 2. Örgütsel Adalet, Etik Liderlik, Bağlamsal Performans Ölçekleri Normal Dağılım Değerleri

\begin{tabular}{|c|c|c|c|c|c|}
\hline \multirow{2}{*}{$\begin{array}{l}\text { Değişkenler } \\
\text { Örgütsel Adalet }\end{array}$} & \multirow{2}{*}{$\begin{array}{l}\text { Min-Max } \\
\text { Statistic } \\
\text {,108 }\end{array}$} & \multicolumn{2}{|c|}{ Skewness } & \multicolumn{2}{|c|}{ Kurtosis } \\
\hline & & $\begin{array}{c}\text { Statistic } \\
, 136\end{array}$ & $\begin{array}{c}\text { Std.Error } \\
-, 811\end{array}$ & $\begin{array}{c}\text { Statistic } \\
, 272\end{array}$ & Std.Er \\
\hline Etik Liderlik & &,- 001 & 136 & -940 & 272 \\
\hline Bağlamsal Perfo & &,- 198 & , 136 & -609 & 272 \\
\hline
\end{tabular}


Katılımcıların örgütsel adalet algıları, etik liderlik algıları ve bağlamsal performansları arasındaki ilişkiyi belirlemeye yönelik korelasyon analizi sonuçları ile ölçek puan ortalamaları Tablo 2'te gösterilmiştir.

Tablo 3. Örgütsel Adalet Etik Liderlik Bağlamsal Performans korelasyon analizi

\begin{tabular}{|c|c|c|c|c|c|}
\hline Değişkenler & Ortalama & & Örgütsel Adalet & Etik Liderlik & $\begin{array}{c}\text { Bağlamsal } \\
\text { Performans }\end{array}$ \\
\hline $\begin{array}{c}\text { Örgütsel } \\
\text { Adalet }\end{array}$ & 3,15 & $\mathrm{r}$ & 1 &, $587^{* *}$ &, $357^{* *}$ \\
\cline { 3 - 6 } & $\mathrm{p}$ & $\mathrm{r}$ &, $587^{* *}$ &, 000 &, 000 \\
\hline \multirow{2}{*}{\begin{tabular}{c} 
Etik Liderlik \\
\cline { 3 - 6 }
\end{tabular}} & 3,29 & $\mathrm{p}$ &, 000 & 1 &, $613^{* *}$ \\
\hline $\begin{array}{c}\text { Bağlamsal } \\
\text { Performans }\end{array}$ & 3,47 & $\mathrm{r}$ &, $357^{* *}$ &, $613^{* *}$ & 1 \\
\cline { 3 - 6 } & $\mathrm{p}$ &, 000 &, 000 & \\
\hline
\end{tabular}

Tablo 3’te görüldüğü gibi bağımsız değişken Örgütsel Adalet ile Bağlamsal Performans $\left(\mathrm{r}=, 357^{* *} \mathrm{p}=, 000\right)$ arasında anlamlı ve pozitif bir ilişki bulunmaktadır. Örgütsel Adalet ile Etik Liderlik $\left(r=, 587^{* *} ; \mathrm{p}=, 000\right)$ arasında anlamlı ve pozitif bir ilişki bulunmaktadır. Son olarak Etik Liderlik ile Bağlamsal Performans arasındaki ilişki incelenmiş ikisi $\left(\mathrm{r}=-, 613^{* *} ; \mathrm{p}=, 000\right)$ arasında anlamlı ve pozitif bir ilişki olduğu gözlemlenmiştir.

Çalışmanın hipotezlerini test etmek için regresyon analizi yapılmıştır.

Tablo 4. Örgütsel Adaletin Bağlamsal Performans Üzerindeki Etkisi

\begin{tabular}{|c|c|c|c|c|c|c|c|}
\hline \multirow{2}{*}{ Değişken } & \multicolumn{2}{|c|}{$\begin{array}{l}\text { Standartlaşmam } \\
\text { 1ş Katsayılar }\end{array}$} & $\begin{array}{l}\text { Standartlaştırıl } \\
\text { mış Katsayılar }\end{array}$ & \multirow{2}{*}{$t$} & \multirow{2}{*}{ p. } & \multirow{2}{*}{$\mathbf{F}$} & \multirow{2}{*}{$\begin{array}{l}\text { Model } \\
\text { (p) }\end{array}$} \\
\hline & $\mathbf{B}$ & $\begin{array}{l}\text { Std. } \\
\text { Error }\end{array}$ & Beta & & & & \\
\hline Sabit (BP) & 2,050 &, 214 & & 9,559 & ,000 & \multirow{2}{*}{46,526} & \multirow{2}{*}{, $000 *$} \\
\hline Örgütsel Adalet & ,452 & ,066 & ,357 & 6,821 & $\begin{array}{l}, 000 * \\
*\end{array}$ & & \\
\hline$R^{2}:$,128; $\quad R:, 357$ & \multicolumn{3}{|c|}{${ }^{*} \mathbf{p}<\mathbf{0 . 0 0 0 ,} \quad{ }^{* *} \mathbf{p}<\mathbf{0 , 0 0}$} & & & & \\
\hline
\end{tabular}




\section{T.Büyükbese-H.Gündoğdu Örgütsel Adaletin Bağlamsal Performans...}

Araştırmanın ilk hipotezi "H1: Örgütsel adaletin bağlamsal performans üzerinde pozitif yönde anlamlı etkisi vardır." şeklinde oluşturulmuştur. $\mathrm{Bu}$ bağlamda değişkenlere ait basit regresyon analizi Tablo 4'te verilmiştir. Tablo 4 incelendiğinde $\mathrm{H} 1$ hipotezinin kabul edildiği sonucuna ulaşılmıştır. Örgütsel adaletin bağlamsal performansı $\% 12,8$ oranında açıkladığı tespit edilmiştir.

Araştırmanın "H2: Örgütsel adaletin etik liderlik üzerinde pozitif yönde anlamlı etkisi vardır" şeklinde oluşturulmuştur. Bu bağlamda değişkenlere ait basit regresyon analizi Tablo 5'te verilmiştir.

Tablo 5. Örgütsel Adaletin Etik Liderlik Üzerindeki Etkisi

\begin{tabular}{|c|c|c|c|c|c|c|c|}
\hline \multirow{2}{*}{ Değişken } & \multicolumn{2}{|c|}{$\begin{array}{l}\text { Standartlaşmam } \\
\text { 1ş Katsayılar }\end{array}$} & $\begin{array}{l}\text { Standartlaştırıl } \\
\text { mış Katsayılar }\end{array}$ & \multirow{2}{*}{$-\mathbf{t}$} & \multirow{2}{*}{ p. } & \multirow{2}{*}{$\mathbf{F}$} & \multirow{2}{*}{$\begin{array}{l}\text { Mode } \\
\text { l } \\
\text { (p) }\end{array}$} \\
\hline & B & $\begin{array}{l}\text { Std. } \\
\text { Error }\end{array}$ & Beta & & & & \\
\hline \multirow{2}{*}{$\begin{array}{l}\text { Sabit (EL) } \\
\text { Örg Adalet }\end{array}$} & 1,707 & ,117 & & $\begin{array}{l}14,63 \\
5 \\
\end{array}$ & ,000 & \multirow[b]{2}{*}{$\begin{array}{l}-167,41 \\
8\end{array}$} & \multirow{2}{*}{, $000 *$} \\
\hline & ,439 & ,034 & ,587 & $\begin{array}{l}12,93 \\
9\end{array}$ & $\begin{array}{l}\text {,000* } \\
*\end{array}$ & & \\
\hline $\mathbf{R}^{2}:$,345; $\quad \mathbf{R : , 5 8 7}$ & $* \mathbf{p}<0$ & 00 , & $p<0,00$ & & & & \\
\hline
\end{tabular}

Tablo 5 incelendiğinde $\mathrm{H} 2$ hipotezinin kabul edildiği sonucuna ulaşılmıştır. Örgütsel Adaletin etik liderliği \%34,5 oranında açıkladığı bulunmuştur.

Araştırmanın 3. hipotezi "H3:Etik liderliğin bağlamsal performans üzerinde pozitif yönde anlamlı etkisi vardır." şeklinde oluşturulmuştur. Bu bağlamda değişkenlere ait basit regresyon analizi tablo 6'te verilmiştir.

Tablo 6. Etik Liderliğin Bağlamsal performans Üzerindeki Etkisi

\begin{tabular}{|c|c|c|c|c|c|c|c|}
\hline \multirow{2}{*}{ Değişken } & \multicolumn{2}{|c|}{$\begin{array}{l}\text { Standartlaşmamış } \\
\text { Katsayılar }\end{array}$} & $\begin{array}{l}\text { Standartlaştırıl } \\
\text { mış } \\
\text { Katsayılar } \\
\end{array}$ & \multirow{2}{*}{$\mathbf{t}$} & \multirow{2}{*}{ p. } & \multirow{2}{*}{$\mathbf{F}$} & \multirow{2}{*}{$\begin{array}{l}\text { Model } \\
\text { (p) }\end{array}$} \\
\hline & B & $\begin{array}{l}\text { Std. } \\
\text { Error }\end{array}$ & Beta & & & & \\
\hline \multirow{2}{*}{$\begin{array}{c}\text { Sabit (BP) } \\
\text { Etik Liderlik }\end{array}$} & 1,566 & ,144 & & 10,879 & ,000 & \multirow{2}{*}{$\begin{array}{l}-191,71 \\
8\end{array}$} & \multirow{2}{*}{,000* } \\
\hline & ,580 & ,042 & 613 & 13,846 & $\begin{array}{l}\text {,000* } \\
*\end{array}$ & & \\
\hline $\mathrm{R}^{2}:$,376; $\quad \mathrm{R}:$, & $*_{\mathrm{p}}$ & Do, & $\mathbf{p}<\mathbf{0 , 0 0}$ & & & & \\
\hline
\end{tabular}


Tablo 6 incelendiğinde anlamlılık değerinin 0,05 'ten küçük olduğu ve istatistiksel olarak H3 hipotezinin kabul edildiği sonucuna ulaşılmıştır. Etik liderliğin bağlamsal performansı \%37,6 oranında açıkladığı bulunmuştur.

\section{Araştırma Modeli "Örgütsel Adalet İle Bağlamsal Performans İlişsisinde Etik Liderliğin Aracı Rolü”}

Aracılık modellerinin analizinde çeşitli yaklaşımlar bulunmaktadır. Bu çalışmada Baron ve Kenny'nin nedensel adım yaklaşımı göz önüne alınarak değerlendirme yapılmıştır.

Araştırmanın son hipotezi "H4: Örgütsel adaletin bağlamsal performans üzerindeki etkisinde etik liderliğin aracılık rolü bulunmaktadır" olarak düzenlenmiştir. $\mathrm{Bu}$ doğrultuda etik liderliğin aracılık etkisine yönelik modeller Şekil 4'te verilmiştir.

A
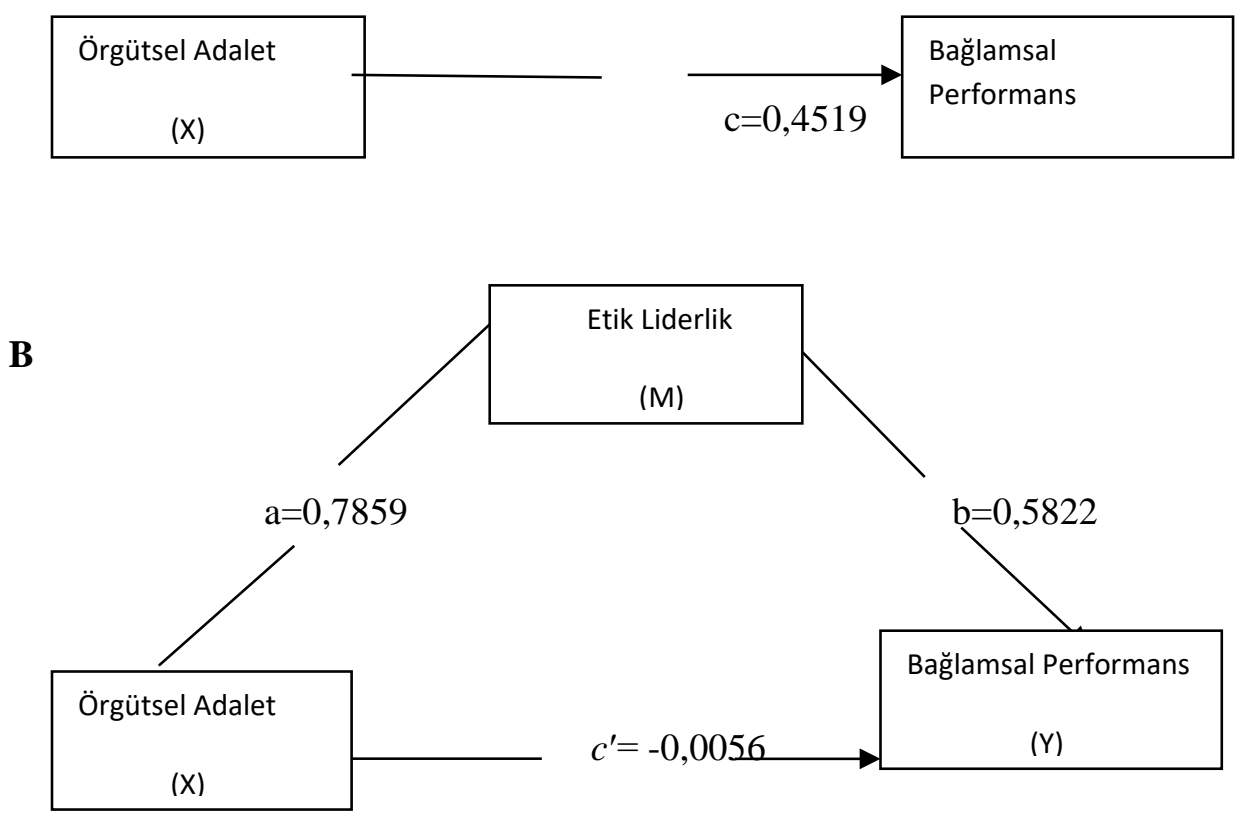

Şekil 4. Örgütsel Adaletin Bağlamsal Performansa etkisinde Etik Liderliğin Arac1 Rolü Modeli 


\section{T.Büyükbese-H.Gündoğdu Örgütsel Adaletin Bağlamsal Performans...}

Şekil 4'te yukarda yer verilen model(A) basit etki modeli olup örgütsel adalet algısının bağlamsal performans üzerinde ki etkisi c yolu ile gösterilmiştir. Bu etki toplam etki olarak adlandırılmaktadır. Altta yer verilen model(B) ise aracılık etkisini göstermektedir. Örgütsel adaletin bağlamsal performans üzerine etkisi, aracı değişken olan etik liderlik aracılığıyla sağlanmaktadır. Bu modelde örgütsel adaletin etik liderlik üzerindeki etkisi a yolu ile etik liderliğin bağlamsal performans üzerindeki etkisi b yolu ile gösterilmiştir. Örgütsel adalet ile aracı değişken olan etik liderlik aynı anda modele dâhil edildiğinde, örgütsel adaletin bağlamsal performans üzerindeki etkisi c' yolu ile gösterilmiştir.

H4 hipotezini ölçmek için, aracılık modelini test etmede geçerli olan özellikler doğrultusunda analizler yapılmıştır. Bu analizlere Tablo 6'da yer verilmiştir.

Tablo 7. Örgütsel Adaletin Bağlamsal Performansa Etkisinde Etik Liderliğin Aracı Rolünün Analiz Verileri

\begin{tabular}{|c|c|c|c|c|c|c|c|c|c|}
\hline & & & & & & & & & $\begin{array}{l}\text { Model } \\
\text { sonucu }\end{array}$ \\
\hline Model & Beta & Se & LLCI & ULCI & $\mathrm{T}$ & $\mathrm{p}$ & R2 & $\mathrm{p}$ & Kabul \\
\hline C & 0,451 & ,066 & ,321 & ,582 & 6,821 & ,000 & ,127 & ,000 & (Tam \\
\hline $\mathrm{a}$ & 0,785 & ,060 & ,666 & ,905 & 12,939 & ,000 & 344 & ,000 & \\
\hline b & 0,582 & 051 & ,480 & ,684 & 11,237 & ,000 & ,376 & ,000 & \\
\hline$c^{\prime}$ & 0,005 & ,069 &,- 142 & 130 &,- 081 & ,935 & & & \\
\hline
\end{tabular}

Tablo 7 incelendiğinde etik liderlik değişkeni (c') aracı değişken olarak analize dahil edildiğinde $\mathrm{p}$ değerinin anlamsız $(\mathrm{p}=, 935)$ olduğu görülmektedir. $\mathrm{Bu}$ da örgütsel adaletin bağlamsal performansa etkisinde etik liderliğin tam aracı rolü olduğunu kanıtlamaktadır. H4 hipotezi kabul edilmiştir.

\section{TARTIŞMA VE SONUÇ}

$\mathrm{Bu}$ çalışma hizmet sektöründe yer alan özel güvenlik çalışanlarının örgütsel adalet algısının bağlamsal performanslarına etkisinde etik liderlik algısının aracı rolünü belirlemek ve etik liderlik, örgütsel adalet ve bağlamsal amaciyla yapılmıştır. Araştırmada nicel veri analizi kullanılmış toplanan 320 anket Spss ve Amos programı ile analiz edilmiştir. 
Elde edilen bulgular örgütsel adaletin bağlamsal performans üzerinde pozitif etkisi olduğunu göstermiştir. Bu sonuç daha önce yapılan Turfail, Mahesar ve Pahtan (2017), Doğan (2014), Devonish ve Greenidge (2010)'ün çalışmalarındaki örgütsel adaletin bağlamsal performans üzerinde etkisinin olduğu sonucu ile de uyuşmaktadır.

Örgütsel adaletin etik liderlik üzerindeki etkisini ölçmek amacıyla yapılan analiz sonucunda örgütsel adaletin etik liderlik üzerinde pozitif etkisi olduğu sonucu elde edilmiştir. H2 hipotezi kabul edilmiştir. Bu sonuç Sonğur, Özer ve Şahin (2017) ile Büyükyılmaz ve Ay (2017)'ın çalışmasında elde ettikleri etik liderlik algısının örgütsel adalet üzerinde pozitif yönde anlamlı etkisi vardır sonucu ile paralellik göstermektedir.

Araştırmada etik liderliğin bağlamsal performans üzerine pozitif etkisi olduğu sonucu gözlemlenmiştir. Bu sonuç Bıyık, Şimşek ve Erden, (2017) çalışmasında elde ettikleri etik liderliğin iş performansı üzerinde anlamlı bir etkisinin olduğu sonucunu desteklemektedir. Aynı şekilde Yasan, Doğan ve Mengi (2019) de iç denetçiler üzerinde yaptığı çalışmada benzer bulgulara ulaşmıştır.

Katılımcıların örgütsel adalet algılarının bağlamsal performansları üzerindeki etkisinde etik liderlik algılarının aracı rolü incelenmiş ve örgütsel adaletin bağlamsal performans üzerine etkisinde etik liderliğin tam aracı rolü olduğu tespit edilmiştir.

Örgütsel adalet, iş performans1, etik liderlik üzerine çalışan (Turfail, Mahesara ve Pahtan, 2017), (Devonish ve Greenidge, 2010), (Doğan, 2018) (Halbussi vd., 2019), (Büyükyılmaz ve Ay, 2017), (Sonğur, Özer ve Şahin, 2017), (İnak, Özkoç ve Kırıc1, 2018), (Sabır, vd. 2012), (Tamer, 2017), (Yasan, Doğan ve Mengi 2019),(Bıyık, Şimşek ve Erden, 2017) gibi yazarlarla aynı doğrultuda sonuçlar elde edilmiştir. $\mathrm{Bu}$ doğrultuda çalışmada elde edilen sonuçların literatür bulgularıyla aynı yönde paralellik gösterdiği ifade edilebilir. Bu çalışmada ise özel güvenlik görevlileri bağlamında ilgili değişkenler arası ilişkiler araştırma konusu yapılmıştır.

Örgütsel adalet, etik liderlik ve bağlamsal performans arasında ilişkiyi incelemek için korelasyon analizi yapılmıştır. Bu analiz sonucunda örgütsel adalet, etik liderlik ve bağlamsal performans arasında anlamlı ve pozitif bir ilişki bulunmuştur. Örgüt yöneticileri ve çalışanların ilişkilerinde bu kavramların önem teşkil ettiğini, göz ardı edilmemesi gerektiğini söyleyebiliriz. Çalışma sonuçlarına göre; etik davranışlar sergileyen, çalışanlarının isteklerini dikkate alan, tarafsız ve önyargısız davranan, çalışanların hakkını adil bir şekilde savunan (Zhu, May ve Avolio, 2004: 18) diğer bir ifadeyle etik lider tarafından yönetilen, örgüt içindeki ilişkilere bağlı olarak ortaya çıkan kazanımların adil dağılımını ve bu dağılım yapılırken izlenen prosedürler ile yöneticilerin örgüt ve çalışanlarla 


\section{T.Büyükbese-H.Gündoğdu Örgütsel Adaletin Bağlamsal Performans...}

ilgili karar, düzenleme, uygulamalar ile çalışanlara olan davranışlarının çalışanlar tarafından tarafsız ve keyfiyete bağlı olmadan adil olarak algılanmasını ifade eden örgütsel adaletin (İyigün, 2012: 50) sağlandığ1 düşünülen kurumlarda bağlamsal performans da artacaktır. Bağlamsal performans çalışanın iş ortamıyla ilgili olumlu, yapıcı sosyal ilişkiler geliştirmesi ve işine karşı özveriyle çalışması anlamına gelmektedir.

Örgütlerin başarısının çalışanların performansına bağlı olduğunu düşünürsek çalışanların örgütsel adalet ve etik liderlik algılarının örgütlerin başarısında oldukça önemli bir yere sahip olduğunu ifade edebiliriz. Örgütte terfi ceza ödül gibi konularda adaletli olacak bir sitem kurulmalıdır. Her türlü haksızlık algısı yaratabilecek davranışlardan kaçınılmalıdır. Örgütteki yöneticiler bütün çalışanlarına aynı mesafede olmalı ve adaletli olmalıdırlar. Çalışanlarına güvenmeli ve güven vermelidirler. $\mathrm{Bu}$ da çalşsanlarla iyi bir iletişimle gerçekleşebilir. Örgütte çalışanlara kendini ifade etme hakkı verilmelidir. Liderler çalışanlarına firsat eşitliği sağlayarak, çalışanlarının yeteneklerini ve potansiyelini, örgüte sağlayabilecekleri katkıyı görebilmeli bunu göstermelerine fırsat vermelidir. Çalışanların örgüte katkılarının bir karşılığı olmalıdır. Bu karşılık liderlerin adaletli yaklaşımları ile anlamlı olacaktır. Bundan dolayı liderlerin etik davranmaları ve adaletli olmaları gerekmektedir.

$\mathrm{Bu}$ çalışma sadece özel güvenlik sektöründeki bir işletmenin çalışanlarının görüşleri ile sınırlıdır. Gelecek çalışmalar için araştırmacılara örgütsel adalet, bağlamsal performans ve etik liderlik değişkenleri ile farklı sektörlerde çalışanlar üzerinde uygulama yapabilecekleri veya çalışanların davranış ve tutumlarını etkileyen diğer değişkenleri araştırma konusu olarak belirlemeleri tavsiye edilmektedir.

\section{KAYNAKÇA}

Akdoğan, A. ve Demirtaş, Ö. (2014). Etik liderlik davranışlarının etik iklim üzerindeki etkisi: örgütsel politik algılamaların aracı rolü, $A K \ddot{U} \ddot{I I} B F$ Dergisi,16 (1), 107-123.

Aronson, E. (2001). Integrating leadership styles and ethical perspectives, Canadian Journal of Administrative Sciences (4), 244-256.

https://doi.org/10.1111/j.1936-4490.2001.tb00260.x

Aslan, M. ve Yıldırım, A. (2016). Hastanede çalışan hemşirelerde bağlamsal performans ölçeğinin geçerlik ve güvenirliği, Hemşirelik Eğitim ve Araştırma Dergisi, 14 (2), 104-111. 
Baş, G. ve Şentürk, C. (2011). İlköğretim okulu öğretmenlerinin örgütsel adalet, örgütsel vatandaşlık ve örgütsel güven algıları, Educational Administration: Theory and Practice, 17 (1), 29-62.

Bıyık,Y., Şimşek T. Ve Erden, P. (2017). Etik liderliğin çalışanların iş performans1 ve iş tatminine etkisi, Gazi Journal of Economics and Business, 3 (1), 59-70.

Büyükyılmaz, O. ve Alper Ay, F. (2017). Etik liderliğin örgütsel vatandaşl1k davranışına etkisinde örgütsel adaletin aracılık rolü, Hitit Üniversitesi Sosyal Bilimler Enstitüsü Dergisi, 10 (1), 210-233. https://doi.org/10.17218/hititsosbil.305431

Chegini, M.G.(2009). The relationship between organizational justice and organizational citizenship behavior, American Journal of Economics and Business Administration 1 (2), 173-176.

https://doi.org/10.3844/ajebasp.2009.173.176

Christian, M. S., Garza, A.S. and Slaughter, J. E. (2011). Work engagament: a quantitative reviewand test of its relations with task and contextual performance, Personel Psychology, 64, 89-136.

https://doi.org/10.1111/j.1744-6570.2010.01203.x

Dalgın, T. (2015). Yöneticilerin liderlik davranışlarının örgütsel vatandaşlık davranışı üzerindeki etkisi ve örgütsel adalet algısı düzenleyici rolü: muğla konaklama sektörü örneği. [Yayınlanmamış Doktora Tezi]. Muğla Sitkı Koçman Üniversitesi.

Devonish, D. and Greenidge, D. (2010). The effect of organizational justice on contextual performance, counter productive work behaviors, and task performance: nnvestigating the moderating role of ability-based emotional intelligence, International Journal Of Selection and Assessment, 18 (1),7686.

https://doi.org/10.1111/j.1468-2389.2010.00490.x

Doğan, H. (2018). Örgütsel adalet algısı ile iş performansı arasındaki ilişki, Kastamonu Üniversitesi İktisadi ve İdari Bilimler Fakültesi Dergisi, 20 (2), 27-46. DOI: iibfdkastamonu.321871.

Halbussi, H. A., Williams, K.A., Mansoor, H. O., Hassan M. S. and Hammad Hamid, F. A. (2019). Examining the impact of ethical leadership and organizational justice on employees' ethical behavior: does person- 


\section{T.Büyükbese-H.Gündoğdu Örgütsel Adaletin Bağlamsal Performans...}

organization fit play a role?, Ethics\&Behavior. https://doi.org/10.1080/10508422.2019.1694024.

İnak, A., Özkoç, A.G. ve Kırıcı, E. (2018). Otel işletmelerinde etik liderlik davranışını örgütsel adalet üzerine etkisi, Ĭgdır Üniversitesi Sosyal Bilimler Dergisi, 14 (2), 286-309.

İşcan, Ö.F. ve Sayın, F. (2010). Örgütsel adalet, iş tatmini ve örgütsel güven arasındaki ilişki, Atatürk Üniversitesi İktisadi ve İdari Bilimler Dergisi, 24 (4), 195-216.

İyigün, N.Ö. (2012). Örgütsel adalet: kuramsal bir yaklaşım, Istanbul Ticaret Üniversitesi Sosyal Bilimler Dergisi, 11(21), 49-64.

Jawahar, I.M. and Carr, D. (2007). Conscientiousness and contextual performance, Journal of Managerial Psychology, 22(4), 330-340.

https://doi.org/10.1108/02683940710745923.

Karadal, H. ve Özsungur, F. (2017). Hizmet inovasyon davranışı ile psikolojik sermaye ve etik liderlik ilişkisinin incelenmesi: Adana örneği. Uluslararası Yönetim Iktisat ve İşletme Dergisi, 13 (13), 663-672. DOI: 10.17130/ijmeb.2017ICMEB1735477.

Nasurdin,A.M. and Khuan,S.,L. (2011). Organizational justice, age, and performance connection in Malaysia. International Journal of Commerce and Management, 21 (3), 273-290.

https://doi.org/10.1108/10569211111165316.

Novitasari,D., Asbari, M., Rizky Wijaya, M. and Yuwono, T. (2020). Effect of organizational justice on organizational commitment: mediating role of intrinsic and extrinsic satisfaction, International Journal of Science and Management Studies, 3 (3), 96-112. DOI: 10.51386/25815946/ijsmsv3i3p110.

Öcel, H. (2013). Örgüt kimliğinin gücü, algılanan örgütsel prestij ve kişi-örgüt uyumu ile bağlamsal performans arasındaki ilişkiler: örgütsel bağlılığın arac1 rolü, Türk Psikoloji Dergisi,28 (71), 37-53.

Özdüvencioğlu, M. (2003). Algılanan örgütsel adaletin bireylerarası saldırgan davranışlar üzerindeki etkisinin belirlenmesi yönelik bir araştırma, Erciyes Üniversitesi İktisadi ve İdari Bilimler Fakültesi Dergisi, 21, 77-96. 
Piccolo, R.F., Greenbaum, R., Hartog,D.N. and Folger, R. (2010). The relationship between ethical leadership and core job characteristics. Journal Of Organizational Behavior, 31, 259-278. https://doi.org/10.1002/job.627.

Polat, S. ve Celep, C. (2008). Ortaöğretim öğretmenlerinin örgütsel adalet, örgütsel güven, örgütsel vatandaşlık davranışlarına ilişkin algıları, Educational Administration: Theory and Practice, 54, 307-331.

Polatçı, S. (2014). Psikolojik sermayenin görev ve bağlamsal performans üzerindeki etkileri: polis teşkilatında bir araştırma, Ege Akademik Bakış,14 (1), 115-124. DOI: 10.21121/eab.2014118072

Poyraz, K., Kara, H. ve Çetin, S.,A. (2009). Örgütsel adalet algılamalarının örgütsel vatandaşlık davranışlarına etkisine yönelik bir araştırma, Süleyman Demirel Üniversitesi Sosyal Bilimler Enstitüsü Dergisi, 1 (9), 71-91

Sabır, M,S., Iqbal, J.J., Rehman, K.U., Shah, K.A. and Yameen, M. (2012). Impact of corporate ethical leadership and employee performance, International Journal of Business and Social Science, 3(2), 163-171.

Şahin E.T. (2018). Presenteizm (İşte var olamama) ile İs Performansı (Görev Performansi ve Bağlamsal Performans) Arasindaki İlişkilerin Belirlenmesi Üzerine Bir Araştırma, [Yayınlanmamış Yüksek Lisans Tezi], Kastamonu Üniversitesi.

Tabachnick, L.S. ve Fidell, B.G. (2013). Using Multivariate Statistics (Sixth Ed.) Pearson, Boston.

Titrek, O. (2009). Okul türüne göre okullardaki örgütsel adalet düzeyi, Uluslararast Insan Bilimleri Dergisi, 6 (2), 552-573.

Tokgöz, N. (2011). Örgütsel sinisizm, örgütsel destek ve örgütsel adalet ilişkisi: elektrik dağıtım işletmesi çalışanları örneği, Eskişehir Osmangazi Üniversitesi İ̈BF Dergisi, 6 (2), 365-389.

Tufail,M.S., Mahesar, H.A. and Pathan, S.K. (2017). Organizational justice, task and contextual performance: emprical analysis for frontline managers. Grassroots, 51(1), 269-279.

Tuna, M., Bircan, H. Ve Yeşiltaş, M. (2012). Etik liderlik ölçeğinin geçerlilik ve güvenirlik çalışması Antalya örneği, Atatürk Üniversitesi İktisadi ve İdari Bilimler Dergisi, 26, (2). 


\section{T.Büyükbese-H.Gündoğdu Örgütsel Adaletin Bağlamsal Performans...}

Zhu, W., May, D.R. and Avolio, B.J. (2004). The impact of ethical leadership behavior on employee outcomes: the roles of psychological empowerment and authenticity, Journal of Leadership and Organizational Studies, 11 (1), 16-26.

https://doi.org/10.1177\%2F107179190401100104 